\title{
MICRO ENTERPRISES IN SMALLTOWNS, AMHARA REGION, ETHIOPIA: NATURE AND PERFORMANCE ${ }^{1}$
}

\author{
Tegegne Gebre Egziabher ${ }^{2} \&$ Mulat Demeke ${ }^{3}$
}

\begin{abstract}
It is generally believed that micro enterprises have a significant employment contribution and can operate successfully in places like small towns where large and medium enterprises cannot. This however depends on the nature and performance of micro enterprises. This paper studies micro enterprises in small towns with the view of identifying their nature and performance. The study is carried in six small towns of the Amhara region on randomly selected 332 micro-enterprises belonging to different economic activities. The finding revealed that the enterprises are generally characterized by low productivity and stagnation, low level of employment and capital, limited access to financial services, lack of partnership and networking, absence of technical and business skills. To this is added the limited purchasing power of the local people, limited export and poor business environment. A multivariate analysis revealed that the most critical variables affecting the performance of micro enterprises were capital, access to information, licensing and access to telephone services. In order to promote micro-enterprises in small towns, it is therefore essential to provide them with access to finance, improve information availability, improve local business environment and promote the formalization of businesses. Moreover businesses should be encouraged to form network and associations and tap export market. Local demand should also be enhanced through improved agricultural productivity in the hinterland and increased income of town dwellers.
\end{abstract}

\footnotetext{
${ }^{1}$ The final version of this article was submitted in January 2007.

${ }^{2}$ Regional and Local Development Studies, Addis Abeba University

${ }^{3}$ Department of Economics, Addis Abeba University
} 


\section{Introduction}

Small towns are found at the lower level of urban hierarchy and they play an essential role as regional service centers in rural hinterland through direct production linkages and spread effects (Henderlink and Titus, 2002). The collection and distribution roles of small towns link the rural hinterland with the bigger and intermediate towns and cities. These functions of small towns are achieved through myriad of economic activities carried in them. The enterprises housed in them are the ones which enable them fulfill their functions and they also form the basis for their growth and development.

The role of micro enterprises has seen a shift in development literature. Modernization theory assumes that the industrial structure in the third world countries will exhibit a parallel development to what has happened in Europe and USA. Production is concentrated in big towns to exploit agglomeration economies. Small and micro enterprises are believed to disappear eventually. In dependency/dominance theory, small enterprises survive either in direct dependency on the large enterprises or as sub-contractors, petty producers and traders operate in extremely competitive markets with no possibility to earn profit sufficient to invest and grow (Pederson, 1989).

Recently, large scale industrialization schemes have been practiced in many parts of Africa and the developing countries. Under this type of industrialization, most of the expertise, know how, equipments and inputs were imported from abroad. Similarly, most of the profits also left the country in different forms and left hardly a sustainable effect on indigenous micro and small enterprises/informal organizations (MSE/IO) (ECA,1998). This created a space for the development of micro and small enterprises/informal sectors to fill in the development process. Thus the development of MSE/IO began to be seen not as a temporary process but as part of a process of development from below. In this situation small enterprises could grow into large size categories as long as the growth is needed and justified (ECA, 1998).

The MSE/ISO have a number of advantages. They could survive in regions where limited purchasing power and infrastructure prohibit medium and large enterprises. Thus they contribute to decentralized development and regionally balanced growth. MSEs in many developing countries result in higher employment per unit of scarce capital that exceeds their large scale counter parts. Similarly, output per unit of capital is also found out to exceed that which is generated by the larger enterprises (Liedholm and Mead citied in Aeroe, 1992). 
The extent to which these advantages are achieved depends on their nature and performance. Those enterprises which are subsistence and survival have lower prospects to grow and play a role in small town's development. On the other hand those firms which have local and external linkages, make use of innovation and information and which operate under favorable business environment have a better prospect for growth and will have a positive role in small town's development. Which of these micro enterprises are found in small towns of Ethiopia are not clearly known. There is a lack of knowledge regarding the economic performance and structure of these enterprises and whether they could be used as a basis to invigorate development in small towns. Such knowledge forms the basis to promote microenterprises and thereby assist small towns development.

This paper examines local economic activities (enterprises) in small towns of the Amhara region with the view to understand their nature and economic performance.

The specific objectives are

1. To examine the nature of small businesses in small towns in terms of linkages and business environment which affect their performance;

2. To examine the economic performance of small businesses in terms of their income and capital and identify their determinants; and

3. To derive suggestions for the promotion of micro entreprises in smaller urban centers.

The study is conducted in six small towns of the Amhara region: Dogollo, Werilu, Akesta, Tita, Haik and Bati ${ }^{2}$. Five of the towns except Bati are found in the South Wello Zone of the Amhara region while Bati is located in the Oromiya zone of the region. The six towns differ in their size, location and their hinterland though all of them are designated as small towns (Table 1.1).

Table 1.1: Some characteristics of the study towns

\begin{tabular}{|c|c|c|c|c|c|}
\hline 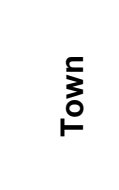 & $\begin{array}{l}\frac{c}{0} \\
\frac{\pi}{\pi} \\
\frac{\pi}{2} \\
0 \\
0 \\
0\end{array}$ & 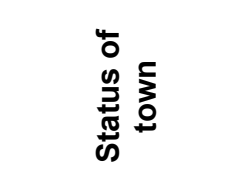 & 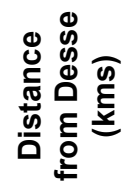 & 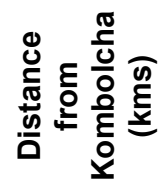 & 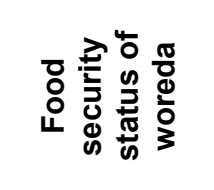 \\
\hline Werilu & 12,908 & Woreda capital & 91 & $\overline{111}$ & Food secure \\
\hline Akesta & 3,488 & Woreda capital & 100 & 120 & Food insecure \\
\hline Bati & 19,504 & Woreda capital & 65 & 42 & Food insecure \\
\hline Dogollo & 4,959 & Woreda capital & 119 & 139 & Food secure \\
\hline Tita & 2595 & Other town & 10 & 30 & Food insecure \\
\hline Haik & 12,000 & Woreda capital & 30 & 50 & Food insecure \\
\hline
\end{tabular}

Source: Field survey 
The primary data for this study were obtained through a sample survey of enterprises. A new sampling frame of businesses was constructed for each town by making doorto-door visits of businesses with the help of knowledgeable local assistants. The woreda municipalities were also consulted regarding the accuracy of the sampling frame. The newly constructed sampling frame was much more comprehensive and inclusive than the list provided by woreda municipality in each town. The enterprises were categorized into trade, services, food and drinks, manufacturing and processing and handicraft. A total of 332 enterprises were randomly selected from the six study towns. From each town, 50 enterprises or more were selected. The enterprises were selected from each category i.e., trade, services, manufacturing, handicraft, food and drinks proportionate to the size of the category.

A structured questionnaire was administered to each selected enterprise. The questionnaire contains information on general characteristics of the business including business type, structure, location, number and type of workers, socioeconomic conditions of the operators etc. In addition, information was also solicited regarding finance, income and sales, credit, business environment, licenses, regulations and taxes.

Frequency tables and means were produced to describe the nature of the businesses. A multivariate analysis was also employed to identify the explanatory factors for the economic performance of the businesses.

The paper is organized in the following way: following this introductory section, section two presents some theoretical views on small and micro enterprises. Section three presents the nature of small businesses in the study area. Section four describes the economic performance of the enterprises by outlining the capital and income characteristics of the businesses. Section five is a multivariate analysis in which factors affecting income and capital of small businesses were discussed. Section six outlines broad policy issues, which have implications for micro enterprise development in small urban centers.

\section{Theoretical views on small and micro enterprises}

Among the major concerns of poor countries are extreme poverty and unemployment. The formal manufacturing or service sector has failed to create enough jobs and the poor have increasingly resorted to informal economic activities. But low returns to the small and micro enterprises and failure of various programs to support the sector have given rise to divergent views and arguments among experts and policy makers. A number of studies have been conducted since the 1980s with the objective of 
identifying appropriate policies and programs to help operators of small and micro enterprises and bring about sustainable development. The objective of this section is to review some of these studies and provide the theoretical framework for the study.

Two strands of ideas on the success of micro enterprises focus on the role of entrepreneur and the role of the environment for small enterprises (Van Dijk, 2005). Arzeni (1998) states that entrepreneurial behavior is a key to accelerating the generation, dissemination and application of innovative ideas. Entrepreneurship is regarded as a strategic assets owing to its non contestable nature (Yu, 2001) . Yu (1998) shows that the dynamics of small manufacturing firms in Hong Kong were principally attributed to adaptive entrepreneurship. Entrepreneurial vision is the key to determine the future of the firm. This implies that since most micro enterprises are led by owner-entrepreneurs, their experience and socio-economic backgrounds limits the capabilities of these firms. Most entrepreneurs of small firms often gain their industry experience from their previous employment and start their own firms via spinoffs (Yu, 2001). Government can accelerate the development small firms by promoting innovation and improving human resource capacity.

Those who emphasize business environment relate economic performance to investment climate of the country (World Bank, 2005). The term business environment encompasses a wide range of policies affecting the economic setting of firms. Chief among these are the regulatory environment, provision of infrastructure and access to primary inputs such as finance, labor, land etc (Lall and Taye, 2005). But there is no consensus over what a sound investment climate for small enterprise growth looks like. The issue of whether the same or different investment climate is needed for large and small enterprises is still debated among experts and policy makers.

Since the nineties more elaborated theories have been used to explain the success of micro and small enterprises. Some of these recent views include flexible specialization, the industrial district or clustering and the network approach. Flexible specialization is based on the manufacture of custom made products by use of multipurpose technology and flexible production methods operated by skilled workers (Helmsing, 2000). In flexible specialization, a firm relies on other firms that specialize in the manufacture of certain components or sub-processes and concentrates on its own sub-component and process serving its own requirement and that of others as well. Inter-firm subcontracting is the basis of sectoral specialization.

The industrial district or cluster approach emphasize that firms found geographically and sectorally clustered benefit from external economies and joint actions. The former is gained from labor market pooling effect, intermediate input effects, 
technological spillover and also access to market (Krugman cited in McCormick, 1999). Joint actions are results of inter-firm cooperation and are manifested in bilateral or multilateral relations. Humprey and Schimitz, (1995) describe that there are two types of joint action namely individual firms cooperating (e.g. sharing equipment or developing a new product) or groups of firms joining forces in business associations, producer consortia and the like.

The network approach views enterprises not as homogenous and independent entities but in a network of enterprises, organizations and households through which commodity, labor, money, information and innovation flow. The network theory sees the production system as a system of specialized enterprises linked to other enterprises (as customers or as producers of inputs, investment goods or services), consumers and workers by a network of commodity, person and information flows (Pederson, 1989). The approach recognizes individual enterprise as dependent on resources controlled by other member of the network. The enterprise gets access to these resources via its position in the network (Johanson and Mattsson, cited in Aeroe, 1992). Its position is influenced by its ability to innovate, which is a function of technological capacity and financial strength and by its local political power and influential contacts (Aeroe, 1992).

In a network theory, a production network does not have to be clustered in space but can take many spatial forms: networks dispersed over wide territories, networks with a 'territorial core' or networks agglomerated highly. Industrial networks may involve only small industries or a mix of small and large firms. The network theory has a broad approach in that the networks are not limited only to production network but include the reproduction of the owner and his family and others. As such the approach gives insight into economically illogical business strategy in small enterprises since it can be understood in terms of a family's overall 'investment strategy'. The approach is thought to be adequate to the African situations since it advocates that the enterprise is dependent not only on other enterprise but also on a broader social network of the owner and his family.

The above theories suggest relevant variables for the success of micro enterprises. Among these are skilled labor, multi-purpose equipment, local and external linkages, the role of innovative entrepreneur, business environment, inter-firm relations, sector and local business associations etc. The following sections analyze the impact and implications of some of these variables in understanding the nature and performance of micro enterprises 


\section{The nature of micro enterprises: Business linkages}

The discussion in this part examines the nature of micro enterprises by identifying the different business linkages: labor market, financial, partnership and cooperation, local and external relations and relations with local authorities.

\section{Employment levels and participation in labor market}

Employment levels vary by type of business types. The total number of people employed in the sampled activities is 601 (Table 3.1). About $64 \%$ of the total employment is accounted by Food and drinks (38\%) and services ( $26 \%)$. Handicraft and cottage and manufacturing and processing generate less employment.

Most of the businesses are single person operated enterprises. Trade, handicraft and services average 1.43 employees per establishment. Those with over 2 persons per establishment are food and drinks (2.48) and manufacturing (2.71) (Table 3.1).

Family labor is by far the most important source of labor. About $74 \%$ of the total workers are family members. Unpaid family labor helps the small enterprises to minimize their cost of operation, but the firms cannot tap the best talents from the labor market.

Table 3.1: Employment in the study area

\begin{tabular}{|c|c|c|c|c|c|c|c|c|c|}
\hline \multirow[b]{2}{*}{ Activity type } & \multicolumn{3}{|c|}{ Hired labor } & \multicolumn{3}{|c|}{ Family labor } & \multicolumn{3}{|c|}{ Total } \\
\hline & 운 & ஃ & 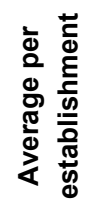 & 운 & ๙ & 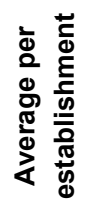 & 우 & ๙ & 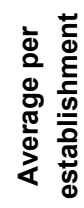 \\
\hline Trade Activities & 12 & 7.7 & 1.50 & 91 & 20.4 & 1.26 & 103 & 17.1 & 1.43 \\
\hline Food and drinks & 79 & 50.1 & 2.19 & 147 & 33.0 & 1.65 & 226 & 37.6 & 2.48 \\
\hline $\begin{array}{l}\text { Manufacturing and } \\
\text { processing }\end{array}$ & 31 & 19.9 & 1.82 & 34 & 7.6 & 1.42 & 65 & 10.8 & 2.71 \\
\hline $\begin{array}{l}\text { Handicraft and } \\
\text { cottage }\end{array}$ & 9 & 5.8 & 2.25 & 41 & 9.2 & 1.21 & 50 & 8.3 & 1.43 \\
\hline Services & 25 & 16.0 & 1.79 & 132 & 29.7 & 1.22 & 157 & 26.1 & 1.43 \\
\hline Total & 156 & 100 & 1.97 & 445 & 100 & 1.36 & 601 & 100 & 1.81 \\
\hline
\end{tabular}

Source: Field survey

The gender dimension of enterprises shows there is a gender-based specialization in the different types of businesses since some sectors are entirely dominated by men 
while others by women (Table 3.2). Table 3.2 shows that about $19 \%$ of the operators are females. A higher participation of females $(78 \%)$ is noted in the food and drinks category.

Perhaps this is not surprising given the fact that businesses in the food and drinks category involve 'injera making and selling'; 'tela and araki making and selling' which are all dominated by women.

The second highest proportion of women, with each accounting for $8 \%$, are found in trade activities and handicraft sector. There are no women participating in manufacturing and processing. A significant proportion of males $(39.2 \%)$ is found mainly in the service sector followed by trade $(25.7 \%)$ and food and drinks $(15.6 \%)$ in that order.

New entrants dominate the labor market, as the operators prior to their present business were students $(25 \%)$, farmers $(14 \%)$, military $(11 \%)$ and unemployed $(10 \%)$. These new entrants might face a great difficulty in establishing a reputation in their business. About $8 \%$ had prior experience in the same line of work while another $9 \%$ have worked in different line of work. Thus it is only a few operators who can bring prior experience to the work. The extent to which employees and owners offer technical capability to the enterprise depends not only on his (her) prior experience as entrepreneur but also on the training background both in the formal, business and technical education.

Table 3.2: Sex of operators by activity type

\begin{tabular}{lccc}
\hline \multicolumn{1}{c}{ Activity type } & Male & Female & Total \\
\hline Trade Activities & 69 & 5 & 74 \\
& $(25.7)$ & $(7.8)$ & $(22.3)$ \\
Food and drinks & 42 & 50 & 92 \\
& $(15.6)$ & $(78.1)$ & $(27.7)$ \\
Manufacturing and processing & 23 & & 23 \\
& $(8.6)$ & 5 & $(6.9)$ \\
Handicraft and Cottage & 30 & $(7.8)$ & 35 \\
& $(11.2)$ & 3 & $(10.5)$ \\
Services & 105 & $(4.6)$ & 108 \\
& $(39.2)$ & 64 & $(32.5)$ \\
Total & 268 & $(100)$ & 332 \\
& $(100)$ & & $(100)$ \\
\hline
\end{tabular}

Source: Field survey

The educational status of the respondents show that $23 \%$ of the business operators had no formal education. Nearly half or $48 \%$ of the female operators fall in this 
category. At the other end of the spectrum, only $4.4 \%$ of the household heads have more than 12 years of education. There is no female respondent with more than 12 years of education. The modal group (32\%) had secondary education. A substantial number $(29 \%)$ also had primary education. These indicate that a significant number of business operators in the study towns have had considerable exposure to formal education. Since the age distribution of the operators shows that most of them (about $35 \%$ ) fall in the age group of 26-36, it is safe to conclude that opportunity for gaining employment in small businesses goes to younger and better educated persons though there are some opportunity for uneducated, older and female group particularly in some activities such as food and drinks. A three-way classification of education by sex and by activity category revealed that the majority of females (79.3 $\%$ ) with no education are engaged in food and drinks.

Notwithstanding the operators' exposition to formal education, the overwhelming majority has neither business nor technical training. Only $3 \%$ reported business training that ranged from 1 month to over 1 year while $1.3 \%$ or four males reported technical training. This, in addition to revealing the labor characteristics, indicates the minimal linkages of business with local and external training institutions. In the absence of technical and business training, a significant proportion (about $13 \%$ ) of the respondents reported that they are engaged in the business because the family has worked in the same line of activity. These individuals must have learned their trade from their parents.

\section{$\underline{\text { Partnership and Cooperation }}$}

Joint venture has a very significant advantage for small enterprises because it enables them to acquire experience and skills and also helps them to enter new markets and secure additional financing. Almost all the businesses in the study area are sole proprietorship. In total, about $97.3 \%$ are run by single owner. There are no subsidiary businesses or share holding companies. Those who reported some form of partnership are only $2 \%$ of the businesses. This is quite in contrast from the experiences of other countries where small business in small towns tend to be subsidiary plants of big companies located somewhere else.

Business associations help to protect the interests of members. The overwhelming majority (98\%) do not belong to any kind of business associations. It is only six enterprises in Tita town, which indicated that they are members of an association. This could be because of Tita's closeness to Dese town which might have prompted some businesses to be part of the association found in Dese. The fact that businesses are not part of any association implies that collective action or joint action 
among operators is non-existent. An enabling institutional policy environment cannot be crated without an organization of small businesses.

\section{Financial linkages: Use of Bank Services and Traditional Financial Institutions}

A relatively more number of businesses in Haik and Bati have bank account for both business and personal savings. In both cases nearly $25 \%$ of the enterprises have bank accounts for business activity while nearly one-third have bank accounts for personal savings. The use of banks in Akesta and Tita is very minimal.

Very few enterprises reported borrowing in the last 12 months. Only 43 establishments or only $13.6 \%$ have borrowed (Table 3.3). The average amount borrowed is 40255.12 birr. The average is relatively big mainly due to a few enterprises that borrowed a significant sum of money from formal banks. A relatively large number of borrowers needed guarantor to take loan.

Table 3.3: Number of businesses who borrowed and average amount by town.

\begin{tabular}{lcc}
\hline Town & Number borrowed & Average amount borrowed \\
\hline Akesta & 3 & 26883 \\
Dogolo & 10 & 17310 \\
Werilu & 8 & 16912.50 \\
Tita & 9 & 544.44 \\
Haik & 7 & 189314.29 \\
Bati & 6 & 1970 \\
Total & 43 & 40255.12 \\
\hline
\end{tabular}

Source: Field survey

The Amhara Credit and Saving and friends and relatives are the main sources of credit for those who borrowed (Table 3.4). Banks and other micro-finance institutions are less important. Those who have borrowed from the banks in total number nine.

Friends and relatives as sources of credit signify the importance of social capital in running a business. In fact about $42 \%$ of the interviewees have indicated that they have a potential to borrow a significant amount of money from friends and relatives at any time. Those who reported that they can rely on friends and relatives as potential borrowers are $43 \%$ in Akesta, $30 \%$ in Dogollo, $28 \%$ in Werilu, $31 \%$ in Tita, $62 \%$ in Haik and $54 \%$ in Bati. The average money mentioned that could be borrowed from friends and relatives is about 8153.37 birr and this could be kept for about 40 days before it is repaid. This signified the importance of friends and relatives as a source of capital for small business in small towns. 
Table 3.4: Source of Credit by town

\begin{tabular}{|c|c|c|c|c|c|c|}
\hline \multirow[b]{2}{*}{ Town } & \multicolumn{5}{|c|}{ Source of credit } & \multirow[b]{2}{*}{ Total } \\
\hline & ग & 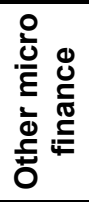 & 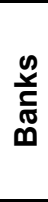 & 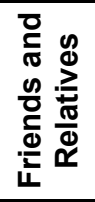 & 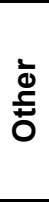 & \\
\hline Akesta & & & & 3 & & 3 \\
\hline Dogolo & 7 & & 2 & 1 & & 10 \\
\hline Werilu & 3 & & 2 & 1 & 2 & 8 \\
\hline Tita & 6 & & 2 & 1 & & 9 \\
\hline Haik & & 1 & 2 & 4 & & 7 \\
\hline Bati & 1 & & 1 & 4 & & 6 \\
\hline Total & 17 & 1 & 9 & 14 & 2 & 43 \\
\hline
\end{tabular}

Source: Field survey

The principal source of fund for initial investment and operating capital is own saving. Over $60 \%$ of the respondents reported own saving for initial investment and over 90 $\%$ reported the same source for operating capital. The second most important source of fund to start the business is found out to be friends and relatives. The two sources together form principal sources of initial investment for over $80 \%$ of the establishments while the proportion of those who reported both sources for working capital are much higher. The importance of banks, moneylenders, government loans etc as source of fund to start businesses is not significant.

Suppliers' credit is not very popular among small businesses. On average, only $20 \%$ of the enterprises reported that they buy items on credit. About $37 \%$ in Haik, $17 \%$ in Bati, enjoy supplier credit. The two towns, Haik and Bati, are relatively bigger centers in the study area. In the remaining towns, only 10 to $13 \%$ of the business use suppliers' credit. Inadequate banking and credit services are among the major constrains of small business in the study areas. Most of the enterprises are forced to operate using a small amount of capital obtained through own savings.

\section{Participation in lquib and Iddir}

Iquib and iddir are traditional means of raising money for different purposes. Iquib involves revolving fund, which is contributed by members. Iddir has more of a social function, assisting members who lost family members or relatives. About one fourth of the interviewees have participated in iquib. The highest is found in Dogolo where a little over half of those interviewed have participated in lquib over the last 12 months. The duration of the iqub is mostly for about 10 months during which time members contribute an average of 313 birr. This money could be drawn from the profit of the 
enterprise and is an indication that those who are participating have a better saving capacity.

Though only $41 \%$ of those who participated responded to the question on the use of money, the majority use the money for business expansion. This indicates that iquib could be used as instrument to promote businesses in the area. A substantial number of those who responded also use their savings from iquib for consumption purposes particularly for food and cloth purchase.

Iddir is more frequently practiced than iqub. About $79 \%$ of the interviewees participate in iddir. The monthly contribution is very low (about 2 birr). Iddir has no role in business expansion since it does not provide loan or could not be used as source of fund for business. The major purpose of iddir as expressed by participant is assistance at times of death. In the absence of a properly functioning credit market and absence of insurance or welfare services, communities need to retain traditional institutions.

\section{Linkage with the local farm sector}

The linkages of business enterprises with the farm sector take three major dimensions. First, the farm sector is a major provider of inputs. Second the farm sector is the major market of the small businesses. Third, the business sector provides inputs to the farm sector. These and other linkages are stronger in situations where the economy is dynamic and growing.

Nearly $38 \%$ of the enterprises use farm produces as inputs for their businesses (Table 3.5). These farm produces, however, come both from local and non-local sources. A quarter of the businesses use entirely local farm produces while a combination of local and non-local farm produces are used by about $5 \%$ of the businesses. Industrial products seem to be the most important input used by over a third of the enterprises. The extent of backward linkage of businesses to the local farm sector is therefore not significant indicating that local agriculture has limited market in the area. On the other hand, however, most businesses (82\%) rely on both farmers and town dwellers as their customers. The farm sector therefore is an important source of market for small businesses in small towns.

A very small number of businesses are engaged in providing inputs for farmers. It is only 20 businesses or $6 \%$ which reported input provision to farmers. These businesses provide fertilizers and seeds. The linkage with the farming sector in terms of input provision is therefore not well developed. With limited use of non-farm inputs, the productivity and income of the rural population remains very small. The extent to 
which farming is also a source of income for business owners was investigated in the study. It is only about 36 business owners or about $11 \%$ who own farm lands with an average size of 0.85 hectares. The farm sector therefore does not serve as supplementary income for the majority of small business operators in the study area.

Table 3.5: Type of inputs used by small businesses*

\begin{tabular}{|c|c|c|c|c|c|c|c|}
\hline & 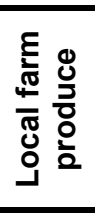 & 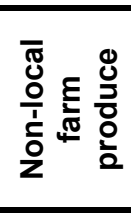 & 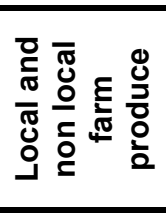 & 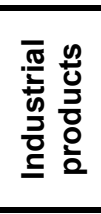 & 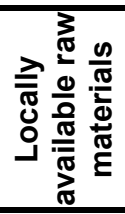 & $\begin{array}{l}0 \\
\stackrel{0}{0} \\
\stackrel{5}{0} \\
0\end{array}$ & $\begin{array}{l}\bar{\pi} \\
\stackrel{0}{0}\end{array}$ \\
\hline \multirow{2}{*}{ Akesta } & 34.4 & & 1.6 & 59.0 & 1.6 & 3.2 & 100 \\
\hline & $(21)$ & & (1) & (36) & (1) & $(2)$ & (61) \\
\hline \multirow{2}{*}{ Dogolo } & 42.0 & 4.0 & 2.0 & 36.0 & 8.0 & 8.0 & 100 \\
\hline & $(21)$ & (2) & (1) & (18) & (4) & (4) & (50) \\
\hline \multirow{2}{*}{ Werilu } & 41.5 & 3.8 & & 37.7 & 1.9 & 15.1 & 100 \\
\hline & $(22)$ & (2) & & (20) & (1) & (8) & (53) \\
\hline \multirow{2}{*}{ Tita } & 16.1 & 25.0 & 5.4 & 25.0 & 5.4 & 23.2 & 100 \\
\hline & (9) & (14) & (3) & (14) & (3) & (13) & (56) \\
\hline \multirow{2}{*}{ Haik } & 9.4 & & 15.1 & 28.3 & 9.4 & 37.7 & 100 \\
\hline & (5) & & (8) & (15) & (5) & (20) & (53) \\
\hline \multirow{2}{*}{ Bati } & 8.6 & 12.1 & 6.9 & 32.8 & 20.7 & 18.9 & 100 \\
\hline & (5) & (7) & (4) & (19) & (12 & (11) & (58) \\
\hline \multirow{2}{*}{ Total } & 25.1 & 7.6 & 5.1 & 36.9 & 7.9 & 17.5 & 100 \\
\hline & (83) & (25) & (17) & $(122)$ & (26) & (58) & (331) \\
\hline
\end{tabular}

Figures in parenthesis are reporting cases

Source: Field survey

* one case did not respond to this question

\section{Local and External Linkage in input sourcing and output distribution}

The local and external linkages of businesses could be examined in terms of the sources of inputs and market places for outputs. The sources and market places were designated as local, regional and national ${ }^{3}$. In terms of inputs, $52 \%$ of the businesses receive their inputs from local sources while nearly $46 \%$ receive from the regional capitals particularly Desse and Kombolcha (Table 3.6). Only very few or $5 \%$ of the enterprises receive their inputs from the national market. Trade and services are by far the most important activities, which receive their inputs from the region. Merchandise trade is involved in locally distributing imported goods from the regional market. The regional linkage is not strong with regard to the outputs of the businesses. All in all about $85 \%$ of the businesses have local markets while only 14 $\%$ supply for regional market. The national market is very insignificant for the businesses in the small towns. Trade and services are the ones, which have a better 
linkage with the regional market. The fact that $85 \%$ of the businesses cater to the local market means that these businesses depend on the low income of the farmers and the residents of the towns. As a result, regional and national exports cannot be the source of growth for the businesses.

Table 3.6: Sources of inputs and destinations of output*

\begin{tabular}{|c|c|c|c|c|c|c|c|c|}
\hline & \multicolumn{4}{|c|}{ Input } & \multicolumn{4}{|c|}{ Output } \\
\hline & Local & Regional & National & Total & Local & Regional & National & Total \\
\hline Trade & $\begin{array}{l}33.3 \\
(24)\end{array}$ & $\begin{array}{l}56.9 \\
(41)\end{array}$ & $\begin{array}{l}9.7 \\
(7)\end{array}$ & 72 & $\begin{array}{c}75 \\
(54)\end{array}$ & $\begin{array}{l}23.6 \\
(17)\end{array}$ & $\begin{array}{c}0.01) \\
1\end{array}$ & 72 \\
\hline Food & $\begin{array}{l}64.8 \\
(61)\end{array}$ & $\begin{array}{l}32.9 \\
(31)\end{array}$ & $\begin{array}{c}2.12 \\
(2)\end{array}$ & 94 & $\begin{array}{c}95 \\
(88)\end{array}$ & $\begin{array}{l}5.3 \\
(5)\end{array}$ & - & 93 \\
\hline Manufacturing & $\begin{array}{l}47.6 \\
(10)\end{array}$ & $\begin{array}{c}38.1 \\
(8)\end{array}$ & $\begin{array}{c}14.3 \\
(3)\end{array}$ & 21 & $\begin{array}{l}76.2 \\
(16)\end{array}$ & $\begin{array}{c}19.0 \\
(4)\end{array}$ & $\begin{array}{c}(4.7) \\
1\end{array}$ & 21 \\
\hline Handicraft & $\begin{array}{l}55.5 \\
(20)\end{array}$ & $\begin{array}{l}38.8 \\
(14)\end{array}$ & $\begin{array}{l}5.5 \\
(2)\end{array}$ & 36 & $\begin{array}{l}80.5 \\
(29)\end{array}$ & $\begin{array}{c}16.6 \\
(6)\end{array}$ & $\begin{array}{l}2.8 \\
(1)\end{array}$ & 36 \\
\hline Services & $\begin{array}{l}49.0 \\
(53)\end{array}$ & $\begin{array}{l}49.1 \\
(53)\end{array}$ & $\begin{array}{l}54 \\
(2)\end{array}$ & 108 & $\begin{array}{l}85.4 \\
(88)\end{array}$ & $\begin{array}{l}12.6 \\
(13)\end{array}$ & $\begin{array}{l}1.9 \\
(2)\end{array}$ & 103 \\
\hline Total & $\begin{array}{c}52.3 \\
(168)\end{array}$ & $\begin{array}{c}(45.8) \\
147\end{array}$ & $\begin{array}{c}(4.9) \\
16\end{array}$ & $\begin{array}{c}100 \\
(321)\end{array}$ & $\begin{array}{c}84.6 \\
(275)\end{array}$ & $\begin{array}{l}13.8 \\
(45)\end{array}$ & $\begin{array}{l}1.5 \\
(5)\end{array}$ & $\begin{array}{c}100 \\
(325 \\
)\end{array}$ \\
\hline
\end{tabular}

Figures in parenthesis are reporting cases

Source: Field survey

*seven cases did not respond to this question

\section{Contact with Local Authorities}

Small businesses make contacts with local authorities in terms of business licenses. A significant proportion, i.e., $52.1 \%$ of the establishments, in the small towns operates without a license. Handicraft and cottage and Services are the two most important activities where the vast majority has no licenses: about $88 \%$ in handicraft sector and $67 \%$ in the service sector are not licensed. Manufacturing and processing is more formal in its operation as the majority (91\%) is licensed.

Licensed enterprises are formal and pay taxes, while the non-licensed ones are informal businesses and may not pay taxes. Formality has its own cost. There is an initial cost of being formal (fees for registration, time spent on the same, licensing, permits to construct workshop etc.) and later the costs of maintaining formality i.e., costs related to renewal of licenses, complying to regulations etc. As a result, most of the micro enterprises choose to stay informal. It should, however, be noted that 
remaining informal has also its own costs such as the costs of illegality, harassment, eviction, lack of access to banks, credit etc.

It is noted that other than linkages for licensing, there is no any other contact what so ever between local authorities and business. It is known that businesses require the inputs and assistance of local authorities to flourish and grow. This linkage however is non-existent and will have its own impact on the performance and growth of the businesses.

\section{Local Business Environment}

Local environment is one of the determinants for the operation of business in small towns. The local environment includes facilities and services available and local policies that could be formulated to impact on local business. These factors influence the performance of business by influencing profitability and production cost.

Tables 3.7 and 3.8 show the economic and financial infrastructure available in the study towns. Economic infrastructure has important implications for business development since they are used as inputs in the businesses. Water and telephone seem to be ubiquitously present in all towns.

Table 3.7: Economic infrastructure available

\begin{tabular}{lcccccc}
\hline & Akesta & Dogollo & Werilu & Tita & Haik & Bati \\
\hline Electricity & No & Yes ${ }^{*}$ & Yes $^{*}$ & Yes & Yes & Yes \\
Piped water & Yes & Yes & Yes & Yes & Yes & Yes \\
Stand pipe water & Yes & Yes & Yes & Yes & Yes & Yes \\
Telephone & Yes & Yes & Yes & Yes & Yes (manual) & Yes \\
Sewerage & No & No & No & No & Yes & Yes \\
Bus stations & No & Yes & Yes & No & Yes & Yes \\
Cattle dip & No & No & No & No & Yes & No \\
Slaughter houses & NF & No & Yes & No & Yes & No \\
\hline
\end{tabular}

* has time limit NF = not functional

Source: Field survey

Electricity is available in bigger towns such as Haik and Bati. In smaller towns electricity is either absent or the service is available for a limited time of the day. Sewerage, bus stations, cattle dip and slaughterhouses are available only in relatively larger towns. Financial services and facilities form important elements of the business environment. Table 3.8 shows that only two towns, Bati and Werilu, have a commercial bank. 
Table 3.8: Availability of financial services

\begin{tabular}{lcccccc}
\hline & Akesta & Dogolo & Werilu & Tita & Haik & Bati \\
\hline $\begin{array}{l}\text { Commercial bank } \\
\text { Amhara rural and credit }\end{array}$ & No & No & Yes & No & No & Yes \\
$\begin{array}{l}\text { savings } \\
\begin{array}{l}\text { Other micro-enterprise } \\
\text { credit }\end{array}\end{array}$ & No & No & Yes & No* & Yes & Yes \\
\hline
\end{tabular}

* Businesses in town get credit from Dese ; Source: Field survey

On the other hand, the Amhara Savings and Credit Institution is found in almost all towns except Tita. Businesses in Tita also use the service of banks in Dese. Primary and secondary schools are available in all the study towns except Tita. By contrast health services are not widely available. Tita and Dogolo do not have any public health facility. Only Akesta has hospital. Almost all towns except Tita are capital cities of their woreda. Their administrative status helps them attract different government services, which in turn create demand for the businesses and serves as center of attraction for further development.

An attempt was made to identify which elements of the business environment prohibit the growth and development of small enterprises in the small towns. Telecommunication, electricity and access to land were respectively indicated by 43 $\%, 46 \%$ and $41 \%$ of the enterprises as forming major obstacles to their businesses. Tax rates and tax administration were also considered as major obstacle by $33 \%$ and $34 \%$ of the businesses respectively while collateral requirement for getting access to finance was regarded as major problem by $24 \%$ of the businesses. Other aspects of the business environment such as regulations, economic policy, corruption, crime, theft and disorders were regarded as obstacles only by a small number of enterprises. Thus infrastructure, land and tax are the major obstacles for the development of small businesses in small towns.

\section{Economic performance of enterprises: Capital and income}

\section{Initial investment, current capital and working capital}

The initial investment of most of the enterprises is found out to be low (Table 4.1). About a quarter $(24.8 \%)$ of all enterprises have an initial investment that ranges between 5-100 birr while a little over half of the enterprises have started their business with initial capital of up to 500 birr. Enterprises in the handicraft and cottage and food and drinks category have the highest proportion of enterprises with very low 
initial investment. About $48 \%$ and $28 \%$ of the enterprises in handicraft and food and drinks category respectively have started their business with a capital amount ranging between 5-100 birr. Those, which have started business with a capital amount up to 500 birr, are $87 \%$ for handicraft and cottage and $66 \%$ for food and drinks. The low initial investment of enterprises is an indication that there is low entry capital barrier for these firms.

Those enterprises with relatively higher initial capital are found in the manufacturing and processing category. About one-third or $32 \%$ of enterprise have started their business with capital that ranges between $2000-5000$ while the majority of enterprises in this category i.e., $36.4 \%$ have started their business with over 20,000 .

The amount of working capital used by the enterprises repeats the patterns observed for the initial investment with slight differences. The working capital in the size category of up to 500 birr is reported by $50.8 \%$ of the enterprises. Enterprises in the handicraft sector have by far the smallest amount of working capital. It is found out that nearly $61 \%$ of the enterprises in this category have reported a working capital of up to 100 birr and nearly $80 \%$ of the enterprises have working capital of up to 500 birr. Manufacturing and trade are those with relatively higher amount of working capital (Table 4.2). The current capital of all businesses is also very small. Generally about $42 \%$ of all businesses have a current capital that is less than 500 birr (Table 4.3). Some sectors such as services and handicraft have a higher proportion of enterprises with less than 500 birr of current capital.

An attempt was made to examine the extent of scale difference or differentiation within the small businesses. The presence of hierarchies or scale differences in any business sector provides dynamism for the sector since it creates a room for expansion. The bigger sectors can lift smaller sectors or create opportunities for small related business activities. In the Fordist industrialization process, technological development is perceived as being an in-plant process. The result could trickle down to other enterprises within a vertical industrial hierarchy (Aeroe, 1992). Within trade, merchandise retail trade and grain trade were examined and it was found out that the majority (66\%) have capital that ranges between 500-10,000. In the food and drinks sector $70 \%$ of the restaurant and cafeteria businesses have capital between 500 $5000,75 \%$ of the tea, pastry, bakery and injera making businesses have capital of less than 500 birr. In the service sector, $74 \%$ of the carpentry, masonry, and plumbing businesses have capital of less than 500 birr. This is an indication that businesses in the small towns are similar and they operate at a similar low level. This prohibits the potential to grow as a result of scale differences. No enterprise is providing opportunity for other enterprises to grow and prosper. 
The expansion possibilities of enterprises is examined by comparing the current capital with the initial capital. About $20 \%$ of the businesses have reported a negative change, which indicates that these enterprises are perhaps de-capitalizing. The remaining $80 \%$ have shown a positive increase in capital accumulation but the level is low. For instance, about $9 \%$ have not shown any capital accumulation, as their current capital is similar with their initial investment. About $26 \%$ have shown an increase in capital accumulation up to $20 \%$ per year while $14 \%$ have shown an increase between 20 and $50 \%$.

The perceptions of operators were sought about the expansion possibilities. A little over half $(51.7 \%)$ of the enterprises indicated that it is not at all possible for expansion. Those who indicated that it is possible to expand are only $10 \%$ of the operators. The operators were asked to rank the most important obstacles for expansion. Lack of working capital was indicated by nearly $54 \%$ as the major problem. Lack of demand was considered by about $23 \%$ while those who mentioned lack of premise at affordable rent are about $6 \%$. These three obstacles are mentioned by $83 \%$ of the enterprises. 
Ethiopian Journal of Economics, Volume XIV, No 1, April 2005

Table 4.1 :Initial investment by activity type*

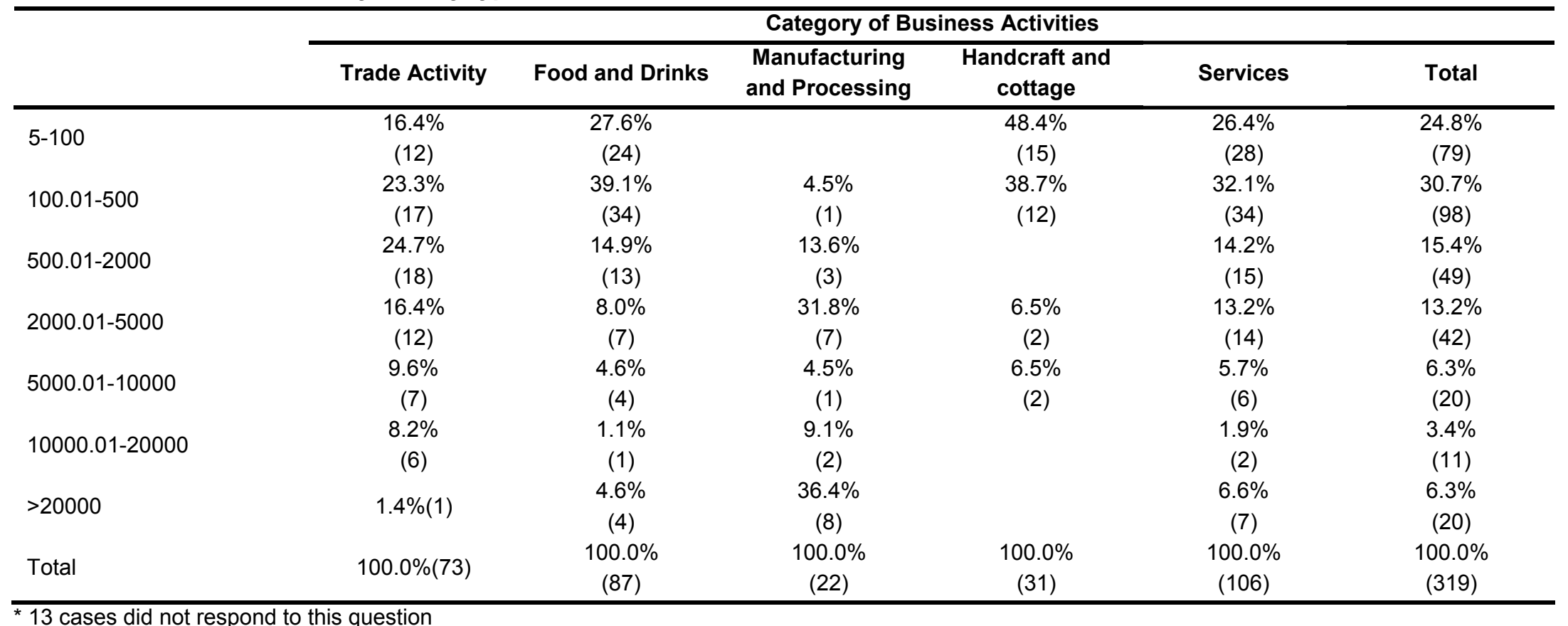

* 13 cases did not respond to this question 
Ethiopian Journal of Economics, Volume XIV, No 1, April 2005

Table 4.2: Working Capital by business category *

\begin{tabular}{|c|c|c|c|c|c|c|}
\hline & \multicolumn{6}{|c|}{ Category of Business Enterprises } \\
\hline & Trade Activities & Food and Drinks & $\begin{array}{l}\text { Manufacturing } \\
\text { and Processing }\end{array}$ & $\begin{array}{l}\text { Handcraft and } \\
\text { cottage }\end{array}$ & Services & Total \\
\hline $0-100$ & $\begin{array}{c}13.5 \% \\
(10)\end{array}$ & $\begin{array}{c}29.5 \% \\
(26)\end{array}$ & & $\begin{array}{c}61.3 \% \\
(19)\end{array}$ & $\begin{array}{c}34.3 \% \\
(37)\end{array}$ & $\begin{array}{c}28.5 \% \\
(92)\end{array}$ \\
\hline $100.01-500$ & $\begin{array}{l}12.2 \% \\
(9)\end{array}$ & $\begin{array}{c}30.7 \% \\
(27)\end{array}$ & $\begin{array}{c}4.5 \% \\
(1)\end{array}$ & $\begin{array}{c}19.4 \% \\
(6)\end{array}$ & $\begin{array}{c}26.9 \% \\
(29)\end{array}$ & $\begin{array}{c}22.3 \% \\
(72)\end{array}$ \\
\hline $500.01-2000$ & $\begin{array}{c}18.9 \% \\
(14)\end{array}$ & $\begin{array}{c}18.2 \% \\
(16)\end{array}$ & $\begin{array}{l}22.7 \% \\
(5)\end{array}$ & $\begin{array}{c}6.5 \% \\
(2)\end{array}$ & $\begin{array}{c}15.7 \% \\
(17)\end{array}$ & $\begin{array}{c}16.7 \% \\
(54)\end{array}$ \\
\hline $2000.01-5000$ & $\begin{array}{c}17.6 \% \\
(13)\end{array}$ & $\begin{array}{c}10.2 \% \\
(9)\end{array}$ & $\begin{array}{l}22.7 \% \\
(5)\end{array}$ & & $\begin{array}{c}9.3 \% \\
(10)\end{array}$ & $\begin{array}{c}11.5 \% \\
(37)\end{array}$ \\
\hline $5000.01-10000$ & $\begin{array}{c}24.3 \% \\
(18)\end{array}$ & $\begin{array}{c}5.7 \% \\
(5)\end{array}$ & $\begin{array}{c}27.3 \% \\
(6)\end{array}$ & $\begin{array}{c}6.5 \% \\
(2)\end{array}$ & $\begin{array}{c}7.4 \% \\
(8)\end{array}$ & $\begin{array}{c}11.5 \% \\
(37)\end{array}$ \\
\hline $10000.01-20000$ & $\begin{array}{c}5.4 \% \\
(4)\end{array}$ & $\begin{array}{c}1.1 \% \\
(1)\end{array}$ & & $\begin{array}{c}6.5 \% \\
(2)\end{array}$ & $\begin{array}{c}1.9 \% \\
(2)\end{array}$ & $\begin{array}{l}2.8 \% \\
(9)\end{array}$ \\
\hline$>20000$ & $8.1 \%(6)$ & $\begin{array}{c}4.5 \% \\
(4)\end{array}$ & $\begin{array}{c}22.7 \% \\
\quad(5)\end{array}$ & $\begin{array}{c}6.5 \% \\
(2)\end{array}$ & $\begin{array}{c}4.6 \% \\
(5)\end{array}$ & $\begin{array}{c}6.8 \% \\
(22)\end{array}$ \\
\hline Total & $100.0 \%(74)$ & $\begin{array}{c}100.0 \% \\
(88)\end{array}$ & $\begin{array}{c}100.0 \% \\
(22)\end{array}$ & $\begin{array}{c}100.0 \% \\
(31)\end{array}$ & $\begin{array}{c}100.0 \% \\
(108)\end{array}$ & $\begin{array}{c}100.0 \% \\
(323)\end{array}$ \\
\hline
\end{tabular}


Ethiopian Journal of Economics, Volume XIV, No 1, April 2005

Table 4.3: Current Capital by business category*

\begin{tabular}{|c|c|c|c|c|c|c|}
\hline & \multicolumn{6}{|c|}{ Category of Business Activities } \\
\hline & Trade Activity & $\begin{array}{l}\text { Food and } \\
\text { Drinks }\end{array}$ & $\begin{array}{l}\text { Manufacturing } \\
\text { and Processing }\end{array}$ & $\begin{array}{l}\text { Handcraft and } \\
\text { cottage }\end{array}$ & Services & Total \\
\hline \multirow{2}{*}{$10-100$} & $8.1 \%$ & $13.6 \%$ & & $45.3 \%$ & $25.0 \%$ & $18.3 \%$ \\
\hline & $(6)$ & $(12)$ & & $(154$ & $(27)$ & $(59)$ \\
\hline \multirow{2}{*}{$100.01-500$} & $14.9 \%$ & $33.0 \%$ & $4.5 \%$ & $32.3 \%$ & $25.0 \%$ & $24.1 \%$ \\
\hline & $(11)$ & $(29)$ & $(1)$ & $(10)$ & $(27)$ & $(78)$ \\
\hline \multirow{2}{*}{$500.01-2000$} & $10.8 \%$ & $17.0 \%$ & $9.1 \%$ & $3.2 \%$ & $12.0 \%$ & $12.1 \%$ \\
\hline & $(8)$ & $(15)$ & $(2)$ & $(1)$ & $(13)$ & $(39)$ \\
\hline \multirow{2}{*}{$2000.01-5000$} & $16.2 \%$ & $14.8 \%$ & $22.7 \%$ & $6.5 \%$ & $13.0 \%$ & $14.2 \%$ \\
\hline & $(12)$ & $(13)$ & (5) & $(2)$ & $(14)$ & $(46)$ \\
\hline \multirow{2}{*}{$5000.01-10000$} & $23.0 \%$ & $9.1 \%$ & $27.3 \%$ & $3.2 \%$ & $8.3 \%$ & $12.7 \%$ \\
\hline & $(17)$ & (8) & (6) & $(1)$ & (9) & $(41)$ \\
\hline \multirow{2}{*}{$10000.01-20000$} & $10.8 \%$ & $2.3 \%$ & $9.1 \%$ & & $6.5 \%$ & $5.9 \%$ \\
\hline & $(8)$ & $(2)$ & $(2)$ & & (7) & (19) \\
\hline \multirow{2}{*}{$>20000$} & $16.2 \%$ & $10.2 \%$ & $27.3 \%$ & $9.7 \%$ & $10.2 \%$ & $12.7 \%$ \\
\hline & $(12)$ & $(9)$ & $(6)$ & (3) & $(11)$ & $(41)$ \\
\hline \multirow{2}{*}{ Total } & $100.0 \%$ & $100.0 \%$ & $100.0 \%$ & $100.0 \%$ & $100.0 \%$ & $100.0 \%$ \\
\hline & $(74)$ & (88) & $(22)$ & (31) & $(108)$ & $(323)$ \\
\hline
\end{tabular}

* 9 cases did not respond 


\section{Sales (revenues) and trends in income}

The sale or revenue data is used to assess the economic status of the enterprises ${ }^{4}$. The survey shows that over half of the enterprises (57\%) reported weekly sales of up to 100 birr. About $90 \%$ of the enterprises have weekly sales of up to 500 birr. Nearly two-third $(65.2 \%)$ of the enterprises in food and drinks category and $59.3 \%$ in services category earn only up to 100 birr per week. Enterprises in 'manufacturing and processing' category are the ones with relatively higher weekly sales. For instance $17 \%$ of the enterprises in manufacturing and processing earn weekly sales that ranges between 500-2000 birr. Enterprises in other categories, which earn income in this category are all less than $9 \%$ (Table 4.4). The distribution of enterprises by revenue category is evident of the low income that is derived by these enterprises.

Notwithstanding, the low level of income, trends in income is an indication whether there is a future for the enterprises in the study towns. The overwhelming majority i.e., $70 \%$ in trade activities, $72 \%$ in food and drinks, $65 \%$ in manufacturing and processing, $71 \%$ in handicraft and cottage and $64 \%$ in services reported that their income is decreasing. The category of enterprises with the highest proportion of enterprises, which reported an increasing trend for income, is services. In this category, nearly $22 \%$ of the enterprises reported an increasing trend. It is, however, worthwhile to mention that those business types in the service category which reported an increase in income are dominated by hotels.

Reasons for decreasing trend for the majority of the enterprises were solicited in the survey. Two reasons that were given by over $70 \%$ of the enterprises in all categories of business are the presence of too many operators and weak purchasing power of the customers. The former indicates that there are too many enterprises and that the market is perhaps over supplied while the latter shows the problem of market mainly because of low income of customers. The major customers for micro enterprises are the hinterland farmers. These farmers who are living in food insecure woredas are impoverished and cannot afford to consume the outputs and services of these enterprises.

About $12 \%$ of the respondents indicated that they use the income they derive from the business for reinvesting in their business or adding a new business. About $64 \%$ or nearly two-third of the businesses uses the income for household consumption. Another $8 \%$ of the enterprises indicated that they use their income both for household consumption and for children education. The fact that the majority uses the income for household consumption indicates that businesses in small towns remain at subsistence level. The extent to which business income is supplemented by other sources of income was also solicited in the questionnaire. About 70 individuals or $22.2 \%$ have reported one additional source of income. This is an indication that there is limited opportunity for income diversification in the study area. 
Ethiopian Journal of Economics, Volume XIV, No 1, April 2005

Table 4.4: Weekly sales/revenue by business category*

\begin{tabular}{|c|c|c|c|c|c|c|}
\hline & \multicolumn{6}{|c|}{ Category of Business Enterprises } \\
\hline & Trade Activities & $\begin{array}{l}\text { Food and } \\
\text { Drinks }\end{array}$ & $\begin{array}{l}\text { Manufacturing } \\
\text { and Processing }\end{array}$ & $\begin{array}{l}\text { Handcraft and } \\
\text { cottage }\end{array}$ & Services & Total \\
\hline $0-100$ & $\begin{array}{c}47.9 \% \\
(35)\end{array}$ & $\begin{array}{c}65.2 \% \\
(60)\end{array}$ & $\begin{array}{c}4.3 \% \\
(1)\end{array}$ & $\begin{array}{c}82.4 \% \\
(28)\end{array}$ & $\begin{array}{c}59.3 \% \\
(64)\end{array}$ & $\begin{array}{c}57.0 \% \\
(188)\end{array}$ \\
\hline $100.01-500$ & $\begin{array}{c}42.5 \% \\
(31)\end{array}$ & $\begin{array}{c}25.0 \% \\
(23)\end{array}$ & $\begin{array}{c}69.9 \% \\
(16)\end{array}$ & $\begin{array}{c}8.8 \% \\
(3)\end{array}$ & $\begin{array}{c}32.4 \% \\
(35)\end{array}$ & $\begin{array}{c}32.7 \% \\
(108)\end{array}$ \\
\hline $500.01-2000$ & $\begin{array}{c}5.5 \% \\
(4)\end{array}$ & $\begin{array}{c}3.3 \% \\
(3)\end{array}$ & $\begin{array}{c}17.4 \% \\
(4)\end{array}$ & $\begin{array}{c}8.8 \% \\
(3)\end{array}$ & $\begin{array}{c}5.6 \% \\
(6)\end{array}$ & $\begin{array}{c}6.1 \% \\
(20)\end{array}$ \\
\hline $2000.01-5000$ & $\begin{array}{c}2.7 \% \\
(2)\end{array}$ & $\begin{array}{c}5.4 \% \\
(5)\end{array}$ & $\begin{array}{c}4.3 \% \\
(1)\end{array}$ & & $\begin{array}{c}2.8 \% \\
(3)\end{array}$ & $\begin{array}{c}3.3 \% \\
(11)\end{array}$ \\
\hline$>5000$ & $\begin{array}{c}1.4 \% \\
(1)\end{array}$ & $\begin{array}{c}1.1 \% \\
(1)\end{array}$ & $\begin{array}{c}4.3 \% \\
(1)\end{array}$ & & & $\begin{array}{c}.9 \% \\
(3)\end{array}$ \\
\hline Total & $\begin{array}{c}100.0 \% \\
(73)\end{array}$ & $\begin{array}{c}100.0 \% \\
(92)\end{array}$ & $\begin{array}{c}100.0 \% \\
(23)\end{array}$ & $\begin{array}{c}100.0 \% \\
(34)\end{array}$ & $\begin{array}{c}100.0 \% \\
(108)\end{array}$ & $\begin{array}{c}100.0 \% \\
(330)\end{array}$ \\
\hline
\end{tabular}

* 2 cases did not report 


\section{Regression analysis}

Two different dependent variables, namely gross sales per week and estimated total capital, were identified for regression analysis in this study. The aim is to understand the determinants of gross sales, which represent business income. Similarly, the scale of operation (captured by total capital of the business) is analyzed to infer about the potential for modernization of the enterprises.

Average weekly sales vary significantly across the different activities and the study towns. For instance, weekly average sales vary from a low of birr 155 for handicraft and cottage to a high of birr 2,803 for manufacturing and processing (Table 4.5). Gross income from services is also low (Birr 271), while those from trade activities and sale of food and drinks are slightly below the overall average. Differences between the towns are also significant, ranging from birr 89 in Tita to birr 1,734 in Bati.

A significant variation is also observed between the different activities and towns with respect to size of business, proxied by total business capital. On the average, the intensity of capital is relatively lower for handicraft and services and higher for food and drinks and manufacturing and processing (Table 4.5). A few relatively big hotels have contributed to larger capital in the food and drink sector.

Table 4.5: Average weekly sales and total capital

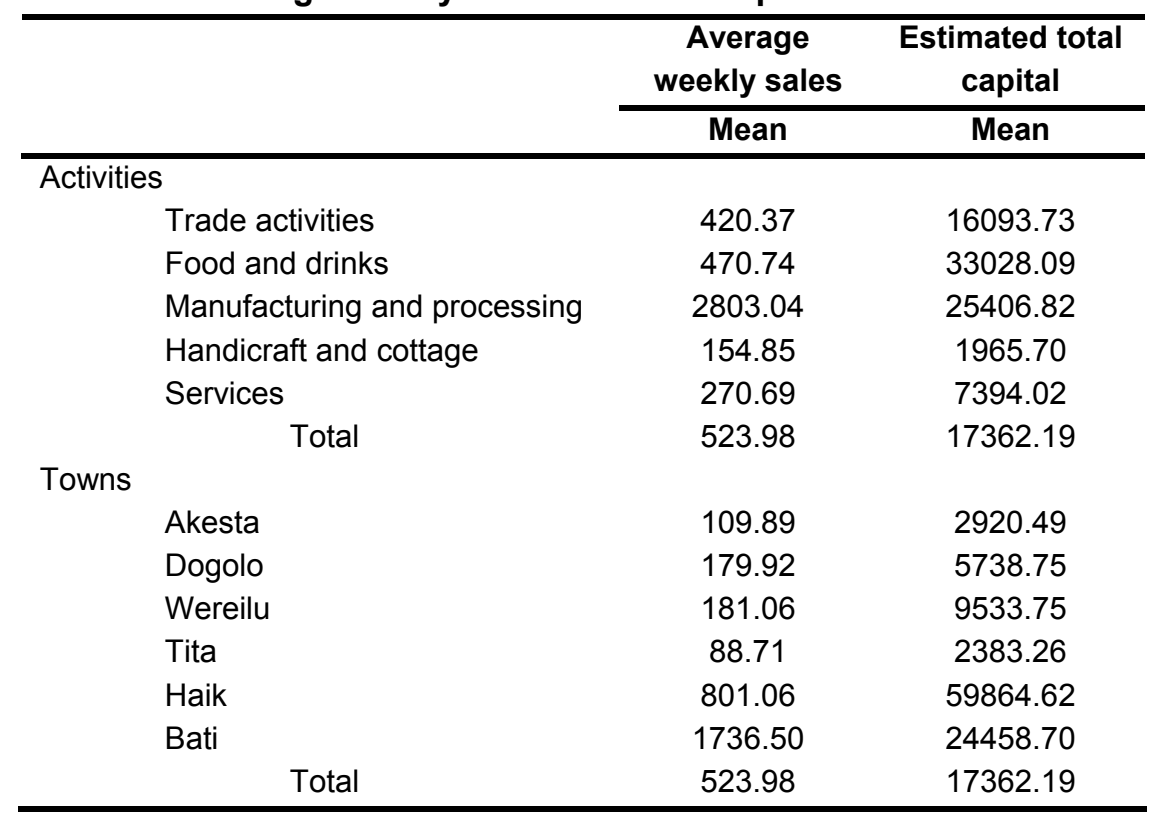




\section{Determinants and results}

\section{Determinants}

A set of several independent variables is thought to influence sales and business capital. These are: Demographic (Education, age, sex); Access to utilities (use of electricity ,use of telephone); Saving effort (use of bank services (open bank account), membership in equib); Government regulation (own business license); Access to information (own radio, own TV); Asset base and income diversification (Own residence house; own business premise); Number of income sources; Access to capital(current working capital); Site dummies( five dummy variables for the six sites); Activity dummies (Four dummy variables for the five activities).

\section{Results of weekly sales}

\section{Demographic factors}

None of the demographic characteristics (education, sex and age ) was found to have a significant influence on the volume of sales. All other factors held constant, female operators do not perform poorly compared to their male counterparts. This is completely different from rural areas where empirical studies show that agricultural performance of female-headed households is lower than that of male-headed families ${ }^{5}$. Women operators of small business are not constrained as much as their female counterparts in rural areas.

It is often argued that education is important in a modern environment. As shown in the descriptive part, most businesses in the study areas do not use modern technologies and operate using mainly their own finance and family labor. A more dynamic environment is perhaps necessary to make education more useful in managing small enterprises.

\section{Access to utilities}

Contrary to the general expectations, the coefficient of electricity is negative and significant. There is no doubt that many small business do not use electric power to undertake their activities. With the exception of some manufacturing and processing plants (e.g. flour mills), electric power is mainly used for lighting purposes. Although access to electric power should have helped to modernize and introduce new technologies and machines, the small business have continued to rely on the same old technologies. Demand constrains as well as lack of finance may have discouraged any modernization effort. Nonetheless, the reasons for failure to utilize the opportunity as well as the unexpected results need further checking and scrutiny. Access to telephone is supposed to remove the constraints to information and 
facilitate networking and partnership. However, the coefficient of telephone is not significant, although it has the expected positive sign. It appears that business operators in the study towns have yet to realize the potential of telephone and associated technologies. Lack of partnership and networking could also undermine the importance of telephone.

\section{Saving efforts}

In the absence of financial services, operators mainly rely on their own savings. Those who save are thus expected to make more effort to improve the performance of their business than those who don't. In this regard, the influence of maintaining a bank account and participating in equib (association for rotation of savings) was tested, and the results show that the two variables positively and significantly influence weekly sales. It appears that business owners with no effort to save face relatively less pressure to perform efficiently.

\section{Access to information}

Information is critical to the social and economic activities of human beings. Operators owning TV and/or radio are more likely to make informed decisions than those who don't. The regression results clearly prove that the performance of owners is significantly better. In the absence of alternative sources of information, access to mass media could be vital to gain knowledge and information about new ways of doing business and to learn about markets (e.g. advertisements). Individuals need to recognize the value of information to build their capacity or human resource capital.

\section{Government support and regulations}

Evidences of government support are non-existent in the study area. Support in the form of training, and improved access to finance, market and new technology is largely unknown. Small enterprises cannot benefit from investment incentives of the government. Regulatory measures to enforce registration, contracts and standards are either weak or absent. The presence of government is felt only in relation to licenses and tax payment. But even these are not uniformly applied as the majority of the businesses operate without license. Nevertheless, license holders consistently performed better than non-holders. This may be attributed to indirect pressure to innovate, improve performance and compete with the unlicensed operators who have no cost of license renewal and taxes.

\section{Access to capital}

The results of the semi-log function for gross revenue showed that revenue is positively and significantly influenced by the amount of working capital. Given that access to credit is very much limited, it is not surprising that enterprises with more capital have managed to produce and sale more. Indeed, the amount of working capital is the single most important determinant of gross revenue in the study towns. 
Asset base and income diversification (risk-taking capacity)

Operators with stronger asset base and with more sources of income are more likely to have better capacity to take risks. Attitudes towards risk generally begin to change as resource base improves and diversifies, and income moves well ahead of minimum consumption needs. Nevertheless, none of the proxy variables to measure risk-taking capacity, i.e. ownership of residence house and business premise or number of income sources, are significant, although all have the expected positive sign. Once again this might be attributed to the absence of modern economic settings where rewards to innovative decisions are higher.

Table 4.6: Model summary

\begin{tabular}{ccccccc}
\hline Model & $\mathbf{R}$ & R.Square & \multicolumn{2}{c}{ Adjusted R Square } & $\begin{array}{c}\text { Std.Error of the } \\
\text { Estimate }\end{array}$ \\
\hline 1 & .824 & .678 & & .650 & & .9048 \\
\hline Table 4.6 contd. & & & & & \\
\hline \multicolumn{2}{c}{ Model } & Sum of Squares & Df & Mean Square & F & Sig. \\
\hline 1 & Regression & 464.657 & 24 & 15.361 & 23.649 & .000 \\
& Residual & 220.226 & 269 & .819 & & \\
Total & 684.883 & 293 & & & \\
\hline
\end{tabular}

Table 4.6 contd.: Regression results: Dependent variable: natural log of sales per week

\begin{tabular}{lrr}
\hline & Unstandardized Coefficients & t- value \\
\hline (constant) & 3.304 & 7.095 \\
Level of education & $1.860 \mathrm{E}-02$ & .3620 \\
Age square & $1.077 \mathrm{E}-05$ & .051 \\
Sex & $-5.703 \mathrm{E}-02$ & -.326 \\
Electricity & -.375 & -2.653 \\
Telephone & .200 & .936 \\
Radio & .290 & 2.109 \\
TV & .426 & 2.108 \\
Own residence & $.679 \mathrm{E}-02$ & .682 \\
Own business premise & .131 & .884 \\
Working capital (natural log) & .256 & 6.217 \\
Bank account & .276 & 1.672 \\
lquib & .251 & 1.936 \\
Number of income sources & $.637 \mathrm{E}-02$ & .382 \\
D-Akesta & -1.122 & -5.800 \\
D-Dogolo & -1.385 & -6.321 \\
D-Wereilu & -1.248 & -6.285 \\
D-Tita & -.753 & -3.485 \\
D-Haik & -.523 & -2.772 \\
License & .559 & 3.377 \\
Age & -.231 \\
D-Trade & $-.422 \mathrm{E}-03$ & -.783 \\
D-Manufacturing and processing & .553 & 2.159 \\
D-Handicarft and cottage & .104 & .465 \\
D-Service & .111 & .627 \\
\hline
\end{tabular}




\section{Site dummies}

All the site dummies are significant and negative, implying that business performance (as measured by weekly volume of sales) in Bati (the control town) is better, holding other factors constant. It should be recalled that Bati has a larger population and is situated on the road to the port of Djibouti/ Assab. As expected, larger population and dynamic business environment positively influence performance.

\section{Activity dummies}

Only the coefficient of the dummy variable for manufacturing and processing is significant and positive among the activity dummies. The result suggests that the performance of the manufacturing and processing sector is better than food and drinks (the control sector) and other sectors.

\section{Result of scale of operation}

As the results above clearly demonstrate, lack of finance (to serve as working or fixed capital) is the most important constraint to the growth and development of small and micro enterprises. Low level of capitalization is also a major characteristic of the firms. Hence, attempts were made to identify factors correlated with the amount of total estimated capital of the sample enterprises. A similar set of independent variables was used in the regression.

Among the variables positively and significantly related to business capital are: telephone, radio, TV, bank account and equib, license and sex. Operators with access to telephone, radio and TV appear to have more capital than those who don't. Similarly, bank account, equib and license are positively related to amount of capital. Moreover, male owners operate with more capital than female owners. Unlike sales, there are no major differences between the study areas in the amount of capital.

Table 4.7: Model summary

\begin{tabular}{ccccc}
\hline Model & $\mathbf{R}$ & R.Square & Adjusted R Square & $\begin{array}{c}\text { Std.Error of the } \\
\text { Estimate }\end{array}$ \\
\hline 1 & .845 & .714 & .692 & 1.3393 \\
\hline
\end{tabular}

Table 4.7 contd. ANOVA

\begin{tabular}{ccccccc}
\hline & Model & Sum of Squares & Df & Mean Square & F & Sig. \\
\hline 1 & Regression & 1255.478 & 21 & 59.785 & 33.329 & .000 \\
& Residual & 504.056 & 281 & 1.794 & & \\
& Total & 1759.534 & 302 & & & \\
\hline
\end{tabular}


Table 4.7 contd. Regression results: Dependent variable: natural log of estimated capital

\begin{tabular}{lrr}
\hline & Unstandardized Coefficients & t-value \\
\hline (constant) & & \\
Level of education & 2.955 & 4.485 \\
Age & $9.400 \mathrm{E}-02$ & 1.249 \\
Age square & $8.274 \mathrm{E}-02$ & 3.054 \\
Electricity & $-8.081 \mathrm{E} 04$ & -2.700 \\
Telephone & -.158 & -.769 \\
Radio & 1.263 & 4.205 \\
TV & .624 & 3.246 \\
Bank account & .882 & 3.068 \\
Iquib & .862 & 3.687 \\
Number of income sources & .390 & 2.064 \\
D-Akesta & .132 & -.763 \\
D-Dogolo & -.479 & -1.725 \\
D-Wereilu & -.211 & -.678 \\
D-Tita & -.440 & -1.542 \\
D-Haik & -.284 & -.934 \\
License & .377 & 1.378 \\
Sex & 1.942 & 8.939 \\
D-Trade & .627 & 2.442 \\
D-Manufacturing and processing & .643 & 2.532 \\
D-Handicarft and cottage & .669 & 1.822 \\
D-Service & -.743 & -2.273 \\
\hline
\end{tabular}

\section{CONCLUSION AND POLICY IMPLICATIONS}

The enterprises are generally characterized by low productivity and stagnation. With no other more productive sector, additional employment is sought through engagement in such enterprises. The capital requirement is very small and the technology is traditional in most cases. Demand for output and services is also very limited as the bulk of the hinterland population is dependent on agriculture that suffers from very low levels of productivity and high degree of uncertainty. Export to other regions is very limited. As a result, too many operators chase limited market, creating no incentive for business expansion. The primary aim is to maintain the same level of operation, with little business and entrepreneurial culture. Access to financial services is limited and partnership and networking are unknown. Skills in business training and technical knowledge are lacking making the enterprises benefit less from the innovative capacity of workers and employees. The majority of operators have joined 
the enterprises for lack of better opportunity. Contact with the local authorities is limited to licensing though the majority does not have appropriate licensing.

Lack of effective linkage with the rural sector is one of the major features of the enterprises. At present, the small towns are not a source of farm input or new technology in the region. Hence, any attempt to develop the local economy cannot be successful unless capacity is created in the enterprises to provide services for transforming rural areas and improving the productivity of small farmers. Sustainable development requires traders, transporters and processors that closely link and network with producers of crop, livestock, forest products, etc. Lack of purchasing power of the local people is cited by majority of the enterprises as the major bottleneck. The main customers of micro-enterprises in small towns are local farmers and local town dwellers. Any improvement in the agriculture sector would thus enhance local demand for goods and services. There must also be serious thought to raise the income of the town dwellers either through subsidies or government activity.

The business environment in terms of infrastructural availability, financial services are not conducive for sustainable development of the enterprises. The major determinant of performance is working capital. Financial resource is critical limiting factor. Because of the expanded market opportunities, larger urban centers are associated with more sales. Access to mass media information, attempts to save and holding license appear to encourage operators to maintain better performance. However, the overall business environment is so weak that human capital and physical infrastructure do not seem to have significant impact.

The theoretical implication of the study is that those elements suggested by the different theories to be crucial for the performance of micro-enterprises are nonexistent or do not seem to explain the performance of enterprises in small towns. Inter-firm relations and other linkages are not features of micro enterprises in small towns. Similarly small towns do not provide conducive business environment critical for the growth and performance.

On the basis of the forgoing descriptive and analytical results policies for small towns businesses could be envisaged. The analytical results point the following:

1. Access to finance: Those enterprises which make use of the bank and iquip are found out to have a higher scale of operation. Adequate provision of finance should be the key element of business development packages. Ways must be sought to ensure that small enterprises benefit from the services of formal commercial banks, specialized banks and micro finance institutions. 
2. Information provisions and consultancy: The role of information in business development has particularly shown a bearing in this study. Enterprises should have access to adequate levels of information about market, technology, research etc.

3. Improving local business environment: It was found out that the use of telephone services has a significant impact on the scale of micro enterprises. Telephone services facilitate business transaction and interaction. In addition, enterprises have indicated that lack of access to land, telephone, and electricity to be the immediate obstacles for their businesses. These and other obstacles related to business environment should therefore be alleviated.

4. Promoting the formalization of businesses: Licensed businesses are found to be better performers in terms of sales and capital amount. The reason could be due to the competitive pressure formalization entails in order to succeed in the market. In addition formal businesses may be the ones which are getting some assistance from the financial and other institutions. Businesses should be promoted to operate formally instead of working as hidden entities since this makes it difficult to realize their potential.

Some pointers from the descriptive part include the following:

5. Enhanced capacity through associations and network: One of the major problems of the enterprises are the limited capacity to tap external market, reduce input cost and avoid competition for a limited market. As the enterprises are operating individually they cannot make use of economies of scale to export. Association formation will enhance their capacity and enable them to tap external market and increase their profit. Partnership should also be encouraged under the umbrella of associations and network

6. Enhance local demand through improved agricultural productivity in the hinterland and increased income of town dwellers: Lack of purchasing power of the local people is cited by majority of the enterprises as the major bottleneck. The main customers of micro-enterprises in small towns are local farmers and local town dwellers. Any improvement in the agriculture sector would thus enhance local demand for goods and services. There must also be serious thought to raise the income of the town dwellers either through subsidies or government activity.

7. Tapping export market: On the demand side, enterprises indicated that there is limited market outside the towns. In order to expand the market, enterprises should tap regional and national export markets in the immediate surrounding or big towns. Thus enterprises in Bati should be able to export to the nearest big market, 
Kombolcha, while enterprises in Haik and Tita should use Dese market. Those at a distance from the big centers such as Legambo, Jamma and Werilu should also be able to use each other's market by depending on their comparative advantage.

\section{End Notes}

${ }^{1}$.This study is sponsored by BASIS (Broadening Access and Strengthening Input Market System ), a research project jointly carried by a consortium of Universities from the US and the Institute of Development Research at the Addis Ababa University, as part of a larger non-farm study. The authors acknowledge BASIS for sponsoring this study.

${ }^{2}$.The selection of these towns is guided by the BASIS project. All towns are within the study woredas of the BASIS project. Within, the study woredas, the study towns are selected because they are the largest towns where some businesses operate.

${ }^{3}$ Local refers to the town and the woreda, regional refers to transactions outside the woreda but within the zone including Dese and Combolcha while national refers to places outside these areas.

${ }^{4}$ Net earnings which relates revenues to costs would have been a better indicator but since the cost data from the enterprises were not realistic, this indicator was not used.

${ }^{5}$ See for instance, Mulat Demeke and Bekele Hundie. 2003. The determinants of yield of major cereals: the contribution of new technology in selected villages of Ethiopia, in Mulat Demeke et al (eds.), Technological Progress in Ethiopian Agriculture, Proceedings of the National Workshop on Technological Progress in Ethiopian Agriculture, Nov. 29-30, 2001, Addis Ababa, Ethiopia. 


\section{REFERENCES}

Aeroe, A. (1992). Rethinking industrialization-from a national to a local perspective: A case study of the industrialization process in Tanzania with particular emphasis on the construction industry. Copenhagen: Center for Development Research.

Arzeni S. (1999). Entrepreneurship and job creation OECD observer, January, pp 19-22

Economic Commission for Africa (ECA) (1998). Micro and small enterprises/Informal enterprises. Unpublished manuscript.

Helmsing, A.H.J. (2000). Externalities, learning and governance. Perspectives on local economic development. Inaugural address, ISS, the Hague, unpublished mansucript.

Hinderink, J. and Titus, M. (2002). Small towns and regional development: Major findings and policy implications from comparative research, urban studies, 39 (3): 379-391.

Humprey John and Schimitz Hubert (1995). Principles for promoting clusters and networks of SMEs. unpublished manuscript

Lall Somik V and Taye Mengiste (2005). Business environment, clustering and industry location: Evidence from Indian cities. World Bank policy research working paper 3675. unpublished

McCormick Dorothy. (1999). African enterprise clusters and industrialization: Theory and reality, World Development, Vol. 27, No.9 pp 1531-1551.

Mulat Demeke and Bekele Hundie (2003). The determinants of yield of major cereals: the contribution of new technology in selected villages of Ethiopia in Mulat Demeke et al (eds.). Technological progress in Ethiopian agriculture, proceeding of a national workshop on technological progress in Ethiopian agriculture, AA.

Pedersen, P. O. (1989). The role of small enterprises and small towns in developing and developed countries. CDR project paper, Copenhagen: Center for Development Research.

Van dik Meine Peter (2005). What explains success of enterprises in Africa' in Tegegne Gebre Egziabher and Bert Helmsing (eds.) Local Economic Development in Africa, pp 186196. The Netherlands: Shaker publishing

World Bank (2005). World Development Report (2005). A better investment climate for everyone.

Yu Tony Fu-Lai (1998). Adaptive entrepreneurship and the economic development of Hong Kong, World Development 26(5) 897-911.

Yu Tony Fu-Lai (2001). Towards capabilities perspective of the small firm, International journal of management reviews , Vol. 3, Issue 3, 185-197 